\title{
Network Economy: An Introduction
}

\author{
Akinwale M. Oteniya, Matthew N. O. Sadiku, and Sarhan M. Musa \\ Roy G. Perry College of Engineering \\ Prairie View A\&M University \\ Prairie View, TX 77446 \\ Email: tennymatt@gmail.com; sadiku@ieee.org; smmusa@pvamu.edu \\ DOI: 10.29322/IJSRP.10.03.2020.p9915 \\ http://dx.doi.org/10.29322/IJSRP.10.03.2020.p9915
}

\begin{abstract}
In few decades, we transitioned from the industrial economy to the IT economy and the Internet economy. The network economy is the next economic revolution. It may be regarded as the convergence of business and consumer networks. It is the business environment that has emerged as a result of ubiquitous information technology allowing access to information anytime and anywhere. This paper expounds the concept of the network economy.
\end{abstract}

Key words: network economy, networked economy, networked information economy, Internet economy

\section{INTRODUCTION}

Networks have served as the means of connecting humans to one another. The modern economy would not exist without the transportation, communications, information, energy, and railroad networks. The Internet (the "information superhighway") is the most important digital network of the last part of the 20th century. It is a global network interconnecting networks and computers [1]. The Internet has been making progress across all parts of our lives in several ways such as online shopping, home banking, bill payments, and emails. The Internet changes everything. As a society, we are becoming more connected and resourceful. Everything we touch, say, and do is connected. We are in the era of hyper-connectivity.

The development of networks makes the main aspects of economic power more and more associated with the ability to control and handle information. Such networks are blurring the boundaries between a company and its environment. This enables companies to search for the most profitable pattern of interactions with other companies for the trades of goods. Pioneering companies that have leveraged such networks to create new business models include Google, Uber, eBay, General Motors, General Electric, Facebook, Microsoft, and IBM.

\section{CONCEPT OF NETWORK ECONOMY}


Network economy (NE) refers to an emerging economic world reliant on information and communication technologies (ICT). It emerged in 1990s and may be regarded as a kind of new economic pattern, a transition from the industrial economy to the networked economy. It is based on modem electronic information technology, enabled by the Internet. It will involve changes in the way goods and services are created, produced, sold, and distributed. The elements of the networked economy are computers, connectivity, and knowledge. These three elements work together to create new economic relationships, as shown in Figure 1 [2].

The idea of a network economy allows fundamental aspects of the new economy to be integrated into one single concept. The new economy is compared with the old as illustrated in Figure 2 [3]. Some see the networked economy as the natural outcome of what happens when all the actors inside a business ecosystem are interconnected. The interconnectedness takes some of the power away from producers of goods/services and puts it in the hands of consumers. At the heart of the network economy is the effective management of finite metabolic and cellular resources.

\section{CHARACTERISTICS}

Network economy may be viewed from a number of perspectives: transition from the industrial economy, digital and information infrastructure, global scale, value networks, and intellectual property rights [4]. It is an emerging type of economic environment in the era of hyperconnectivity and arising from the digitization of fast-growing, real-time connections among people, devices, and businesses. The main feature of the network economy is a radical decentralization of physical capital necessary for the production, storage, distribution, and processing of information.

The three pillars of the networked economy are earning customer loyalty, enabling open innovation, and enhancing resource optimization [5].

1. Earning Customer Loyalty: The networked economy is already helping companies provide better, more personalized customer experiences. Customized delivery capability opens up all kinds of bundling and promotional opportunities.

2. Enabling Open Innovation: The networked economy will create entirely new ways of working. As the first generation of digital natives - people who have never known the world without computers and the Internet - millennials are natural networkers. That is a reality that businesses must embrace to attract the best employees and leverage their talents to fuel true innovation.

3. Enhancing Resource Optimization: The networked economy will make it possible for businesses to use all kinds of resources more efficiently and tap the capacity that we already have. If there is one area where resource optimization is needed more urgently than any other, it is agriculture. 
International Journal of Scientific and Research Publications, Volume 10, Issue 3, March 2020

In the network economy era, information resources have become the main resources in economic activities. Information resources are the main resources. Information is a form of signal, message, or data. It may be useless information or false/harmful information. In network economy, the pervasive flow of economic and financial information will be common.

The twelve principles of the network economy are listed as follows [6]:

1. The Law of Connection

2. The Law of Plentitude

3. The Law of Exponential Value

4. The law of Tipping Points

5. The Law of Increasing Returns

6. The Law of Inverse Pricing

7. The Law of Generosity

8. The Law of Allegiance

9. The Law of Devolution

10. The Law of Displacement

11. The Law of Churn

12. The Law of Inefficiencies

\section{APPLICATIONS}

It would be very difficult, if not impossible, to list every way that network economy has changed our lives. To stay competitive in recent years, companies had to change their inter-firm relationships and focus on their core competences. Network economies are the result of competition on price and quality [7]. The network economy has also quickly found its way into policy-making. Typical applications of network economy are presented as follows.

- Information Marketing: The continuing development of network economy is radically transforming information markets. Based on the modern marketing economy, the network economy has its own ethics, which may be multifold in different 
countries, nations and regions. One benefit of competitive markets is that producers are likely to lose their ability to extract monopoly prices and profits [8].

- Libraries: The value of a library is ability to offer its patrons access to a range of information goods and service. Libraries face new challenges and competition. They compete with alternative storage, retrieval, and distribution systems. They will need to adapt. Consumers increasingly place little value on the value of the content (information) and their ability to find, access, and utilize it [8].

- Internet Economy: This refers to economic activities where Internet acts as the core infrastructure. The Internet is changing many lives and providing a great deal of new wealth to society. The Internet creates value by reducing the costs of transmitting information. The new economy enables businesses to create value by leveraging the Internet to expand their reach to customers and establish virtual markets [9].

- eCommerce: Electronic commerce (ecommerce) is the process of conducting business over computer networks such as the Internet. It has revolutionized business transactions by enabling the consumers to purchase, invest, bank, and communicate from virtually anytime, anywhere. Continuous changes in consumer preferences, technology, and the competitive environment are posing risks and creating opportunities with existing business and operational model. Trust is key to enable eCommerce and interpersonal transactions. Ecommerce has created opportunities for businesses to reach consumers directly [10]. We are beginning to cut out the middle man.

\section{BENEFITS AND CHALLENGES}

In the near future, network economy will offer unprecedented opportunities for innovation, and businesses and improve the lives of billions worldwide. Since information can be shared instantly and inexpensively on a global scale, centralized decision making and expensive bureaucracies are minimized. Large companies will manage their sales, invoicing, and logistics through global networks that connect a billion computing devices without customers being aware of the enterprise physical location [4]. NE creates unprecedented new opportunities for innovation, collaboration, and customization. It is remolding labor market.

As with any revolution, the shift to the networked economy comes with a wide range of challenges that must be addressed. A network economy raises some vital issues with respect to intellectual property, privacy, and security. Ownership is being replaced by access rights. The network economy increases the difficulties of protecting copyrights. Being a newly built economic world, there are not yet laws and ethical standards. Standards are necessary for network economy to function optimally because of two factors: (1) consumer 
expectations and (2) interoperability. Standards provide the information to producers and consumers that enable them to judge the quality and safety of the products [11]. The potential benefits of the NE far outweigh any growing pains.

\section{CONCLUSION}

The development of network economy creates infinite and boundless growth, knowledge-based production, increased productivity, optimal allocation of resources, and the perfect competitive market system. The new economy is meant to designate the future manner of life, which translates into the individual freedom, social and economic autonomy, and the abolition of bureaucratic interventions and regulations of the states [12]. Network economy will act as the engine that drives world development and serve as the carrier of new economic exchanges and social life.

Organizations can no longer be contented doing the same thing they have been doing for years. They must adapt and stay ahead of competitors. The borderless nature of the Web guarantees that in the economy of future will be increasingly global, electronic, and Internet-based. More information about network economy can be found in the books in [13-21].

\section{REFERENCES}

[1] N. Economides, "The Internet and network economics,"

http://neconomides.stern.nyu.edu/networks/Economides_Internet_and_Network_Economics.pdf

[2] "The networked economy: A new way of doing business," 2001

https://slideplayer.com/slide/7368400/

[3] "The place of 'business modelling' within the networked economy,"

https://www.researchgate.net/figure/The-place-of-Business-Modelling-within-the-Networked-Economy-3_fig2_260121763

[4] "Network economy," Wikipedia, the free encyclopedia

.https://en.wikipedia.org/wiki/Network_economy

[5] MIT Technology Review Insights, "Revolution in progress: The networked economy,” August 2014,

https://www.technologyreview.com/s/530241/revolution-in-progress-the-networked-economy/

[6] "Twelve principles of the network economy Kelly,"

https://www.mbaskool.com/business-concepts/marketing-and-strategy-terms/3443-twelve-principles-of-the-network-economy-kevin-kelly.html

[7] P. Cabus and W. Vanhaverbeke, "The territoriality of the network economy and urban networks: Evidence from flanders," Entrepreneurship and Regional Development, vol. 18, no. 1, 2006, pp. 25-53. 
[8] B. J. Bates, "Transforming information markets: Implications of the digital network economy," Proceedings of the American Society for Information Science and Technology, vol. 45, no. 1, 2009.

[9] M. N. O. Sadiku, S. M. Musa, and O. S. Musa, 'Internet economy,” International Journal of Engineering Research and Advanced Technology, vol. 3, no. 10, Oct. 2017, pp. 48-51.

[10] M.N.O. Sadiku, S.M. Musa, and O. D. Momoh, "E-Commerce: A primer," International Journal of Advances in Scientific Research and Engineering, vol. 2, no. 11, Dec. 2016, pp. 21-26.

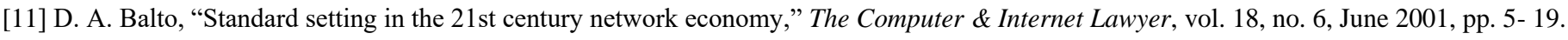

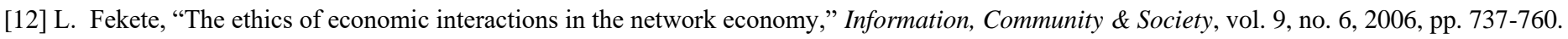

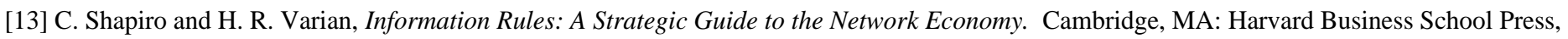
1999.

[14] A. P. de Man, The Network Economy. Edward Elgar Publishing, 2004.

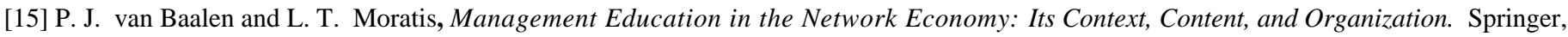
2001.

[16] J. R. Lincoln and M. L. Gerlach, Japan's Network Economy: Structure, Persistence, and Change. Cambridge, UK: Cambridge University Press, 2004.

[17] B. Johanson, C. Kartsson, and L. Wstin (eds.), Patterns of a Network Economy. New York, Springer-Verlag, 1994.

[18] D. Battu, Communication Networks Economy. ISTE- Wiley, 2016.

[19] R. Hassan, The Chronoscopic Society: Globalization, Time and Knowledge in the Network Economy. New York: Peter Lang, 2003.

[20] K. Kelly, New Rules For the New Economy: Ten Radical Strategies for a Connected World. New York, NY: Penguin Group, 1998.

[21] R. Beck, The Network(ed) Economy: The Nature, Adoption and Diffusion of Communication Standards. Springer, 2006.

\section{ABOUT THE AUTHORS}

Matthew N.O. Sadiku (sadiku@iee.org) is a professor at Prairie View A\&M University, Texas. He is the author of several books and papers. He is an IEEE fellow. His research interests include computational electromagnetics and computer networks.

Akinwale M. Oteniya (tennymatt@gmail.com) received his MSc degree from Prairie View A\&M University. His research interests include robotics, micro devices, smart technologies, electrical distribution, cyber security, and big data.

Sarhan M. Musa (smmusa@pvamu.edu) is a professor in the Department of Engineering Technology at Prairie View A\&M University, Texas. He has been the director of Prairie View Networking Academy, Texas, since 2004. He is an LTD Sprint and Boeing Welliver Fellow. 


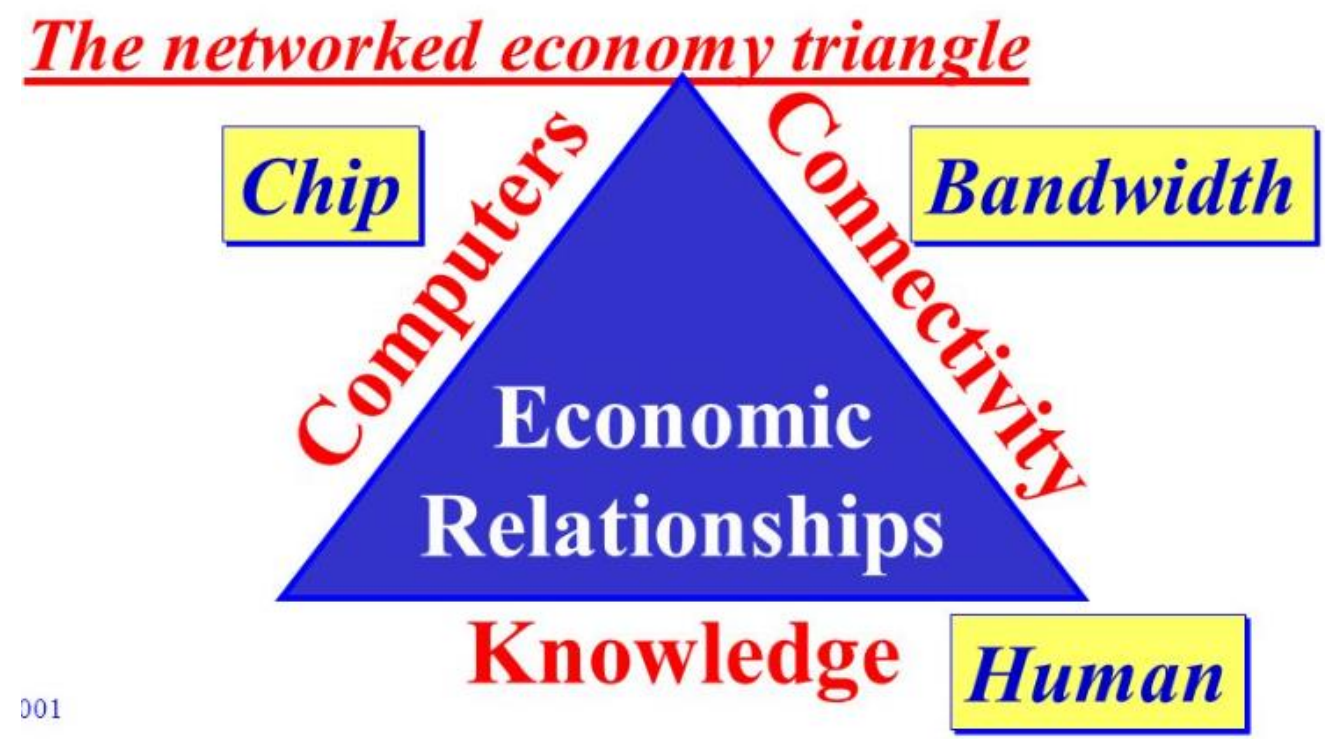

Figure 1 Elements of the network economy [2].

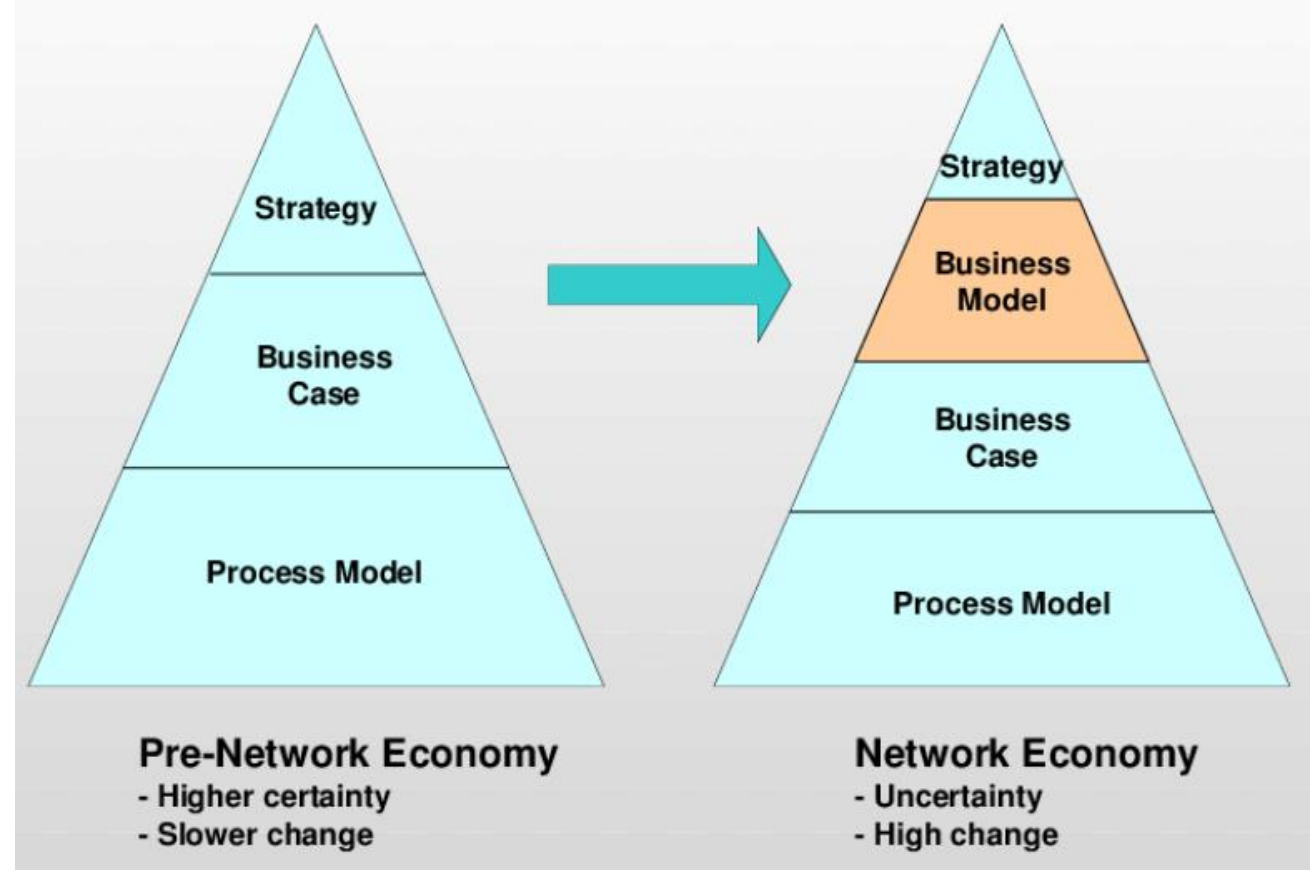

Figure 2 Comparing the network economy with the traditional economy [3] 